\title{
Evaluation of the Effects of Some Brazilian Medicinal Plants on the Production of TNF- $\alpha$ and CCL2 by THP-1 Cells
}

\author{
Grasielle S. Gusman, ${ }^{1}$ Priscilla R. V. Campana, ${ }^{1}$ Luciano C. Castro, ${ }^{1}$ Rachel O. Castilho, ${ }^{1}$ \\ Mauro M. Teixeira, ${ }^{2}$ and Fernão C. Braga ${ }^{1}$ \\ ${ }^{1}$ Department of Pharmaceutical Sciences, Faculty of Pharmacy, Universidade Federal de Minas Gerais, Avenida Antônio Carlos 6627, \\ Campus Pampulha, 31.270-901 Belo Horizonte, MG, Brazil \\ ${ }^{2}$ Department of Biochemistry, Institute of Biological Sciences, Universidade Federal de Minas Gerais, Avenida Antônio Carlos 6627, \\ Campus Pampulha, 31.270-901 Belo Horizonte, MG, Brazil
}

Correspondence should be addressed to Fernão C. Braga; fernao@netuno.lcc.ufmg.br

Received 13 January 2015; Revised 4 March 2015; Accepted 6 March 2015

Academic Editor: Jose M. Prieto

Copyright (C) 2015 Grasielle S. Gusman et al. This is an open access article distributed under the Creative Commons Attribution License, which permits unrestricted use, distribution, and reproduction in any medium, provided the original work is properly cited.

Several plant species are traditionally used in Brazil to treat various inflammatory diseases. Tumor necrosis factor- (TNF-) $\alpha$ and chemokine (C-C motif) ligand 2 (CCL2) are key inflammatory mediators in diseases like rheumatoid arthritis and atherosclerosis, respectively; nevertheless, only a few extracts have been assayed against these targets. We herein report the effect of 19 plant extracts on TNF- $\alpha$ and CCL2 release by lipopolysaccharide- (LPS-) stimulated THP-1 cells, a human monocytic leukemia cell line, along with their radical scavenging activity on DPPH. The extracts of Caryocar brasiliense, Casearia sylvestris, Coccoloba cereifera, and Terminalia glabrescens inhibited TNF- $\alpha$ production in a concentration-dependent manner. Fractionation of these extracts potentiated the anti-TNF- $\alpha$ effect, which was shown to concentrate in polar fractions, mainly composed by polyphenols. Significant CCL2 inhibition was elicited by Lippia sidoides and Terminalia glabrescens extracts, whose fractionation resulted in highly active low polar fractions. All assayed extracts showed strong radical scavenging activity, but antioxidant activity did not correlate with inhibition of TNF- $\alpha$ or CCL2 production. Our results allowed identifying extracts with selective capacity to block cytokine production; therefore, further purification of these extracts may yield molecules that could be useful in the treatment of chronic inflammatory diseases.

\section{Introduction}

Inflammation is a complex physiological response of vascularized tissues to noxious stimuli as pathogens, damaged cells, or irritating agents. Although it is primarily a physiological and beneficial process, nonresolved inflammation can be involved in the pathogenesis and progression of several inflammatory diseases, including rheumatoid arthritis (RA) and cardiovascular diseases (CD) $[1,2]$.

The tumor necrosis factor- (TNF-) $\alpha$ is a key proinflammatory cytokine that mediates apoptosis, inflammation, and immunity and is believed to play a role in various chronic inflammatory diseases including RA, psoriasis, inflammatory bowel disease (IBD), diabetes, cancer, and sepsis [3-5]. Indeed, anti-TNF- $\alpha$ therapy is currently in clinical use for management of RA and IBD. Nevertheless, treatment with biological agents is costly for low income countries and their use may be associated with adverse effects and predisposition to malignancies, especially lymphoma $[6,7]$.

The chemokine (C-C motif) ligand 2 (CCL2) or chemokine monocyte chemoattractant protein- (MCP-) 1 is believed to play a major role in the pathogenesis of hypertensive vascular disease and atherosclerosis $[8,9]$ and may also contribute to the pathogenesis of RA, idiopathic pulmonary fibrosis, and tumors [10]. There appears to be a link between inflammatory processes and hypertension, wherein vascular inflammation plays an important role in the pathogenesis and progression of hypertension [11, 12]. Inflammation participates in all stages of the atherosclerotic process, including endothelial dysfunction, monocyte adhesion and penetration, plaque 
formation and progression, and plaque rupture and thrombosis [11]. CCL2 contributes to the atherosclerotic process as it strengthens the adhesion and promotes monocytes to transmigrate into intima and later mature into macrophages [13].

The imbalance of reactive oxygen species (ROS) generation is recognized to aggravate inflammation. In the last years, considerable attention has been given to the participation of ROS in the pathogenesis of RA and hypertension [14]. ROS such as superoxide anion $\left(\mathrm{O}_{2}{ }^{--}\right)$, hydrogen peroxide $\left(\mathrm{H}_{2} \mathrm{O}_{2}\right)$, and hydroxyl radicals $\left({ }^{\circ} \mathrm{OH}\right)$ can initiate and perpetuate the inflammatory cascade causing additional tissue damage via further activation of NF- $\kappa \mathrm{B}[15]$. On the other hand, there is also evidence to suggest that ROS can reduce the inflammatory process or induce resolution of inflammation [16]. Therefore, ROS seem to play a complex role in inflammation and temporal control of ROS generation can determine their action as pro- or anti-inflammatory agents [2].

Brazil is considered to have the richest biota among the megadiversity countries, possessing $20-22 \%$ of all existing plants and microorganisms [17]. Several plant species are traditionally used in the country to treat different inflammatory conditions. A review of Falcão and collaborators listed 75 plants that have been investigated in the country for their in vivo anti-inflammatory properties [18]. In spite of its rich plant biodiversity and cultural diversity of traditional populations, only a limited number of plant products from Brazil have reached the markets in industrialized countries [19]. Therefore, the investigation of biological properties of Brazilian medicinal plants offers a unique opportunity for drug development.

Continuous studies on the molecular basis of inflammatory processes resulted in the identification of key targets to be exploited for drug development and allowed the investigation of plant extracts in different cell-based assays [20, 21]. Besides the identification of anti-inflammatory plants, this approach also discloses possible cytotoxic effects and furnishes clues on their mechanism of action. Within this context, we have focused our investigation on the effects of Brazilian plants on the production of TNF- $\alpha$ and CCL2 release by THP- 1 cells stimulated by LPS. TNF- $\alpha$ and CCL 2 are key mediators in chronic inflammatory processes like arthritis and atherosclerosis and the plants were selected based on their traditional use to treat these diseases or other inflammatory conditions. We have also investigated the antioxidant properties of the plants using the DPPH assay, since oxidative stress may also contribute to the pathogenesis of arthritis and atherosclerosis.

\section{Material and Methods}

2.1. Plant Materials, Extracts Preparation, and Fractionation. A total of 18 plant species were selected for study based on their traditional uses in Brazil to treat different inflammatory processes (Table 1).

The species were identified by botanists from the Botanical Department, Instituto de Ciências Biológicas, UFMG, Belo Horizonte, Brazil, where voucher specimens are deposited (see Table 1 for voucher numbers). After drying at $45^{\circ} \mathrm{C}$, during $72 \mathrm{~h}$, the plant material was powdered and extracted by exhaustive percolation with ethanol $96 \mathrm{GL}$ at room temperature (Table 2 ). The solvent was removed in a rotatory evaporator at $50^{\circ} \mathrm{C}$ under reduced pressure, to furnish the crude extracts (see Table 2 for extraction yields). Portions $(2 \mathrm{~g})$ of the extracts of the most active plants were dissolved in methanol/water $(3: 7)$ and sequentially partitioned with equal volumes $(3 \times 50 \mathrm{~mL})$ of $n$-hexane, dichloromethane, and ethyl acetate. Solvents were removed in a rotatory evaporator, at maximum temperature of $50^{\circ} \mathrm{C}$, to afford the $n$-hexane, DCM, EtOAc, and water fractions.

2.2. Cell Line and Assay of Inflammatory Mediators. The anti-inflammatory activity of the extracts and fractions was evaluated by measuring TNF- $\alpha$ and CCL2 produced by LPSstimulated THP-1 cells employing an immunoassay [22]. THP-1 cells (ATCC TIB-202) were cultivated in RPMI 1640 medium (Sigma, USA) supplemented with $0.05 \mathrm{mM} \mathrm{2-}$ mercaptoethanol, 10\% FBS (Gibco, USA), $100 \mathrm{U} / \mathrm{mL}$ of penicillin (Sigma Aldrich, USA), and $100 \mu \mathrm{g} / \mathrm{mL}$ of gentamicin (Sigma Aldrich, USA) at $37^{\circ} \mathrm{C}$ in an atmosphere containing $5 \% \mathrm{CO}_{2}$.

The medium was renovated twice a week, when cell concentrations reached $1.0 \times 10^{6}$ cells $/ \mathrm{mL}$. The cells were transferred to a 96-well microplate at a density of 100,000 cells per well, incubated for $18 \mathrm{~h}$, and pretreated with the samples for $3 \mathrm{~h}$. LPS (Sigma Aldrich, USA) was administrated at $100 \mathrm{ng} / \mathrm{mL}$ as inflammatory stimulus. After incubating the plate at $37^{\circ} \mathrm{C}$ overnight, it was centrifuged $(1800 \mathrm{~g}, 5 \mathrm{~min}$, $\left.16^{\circ} \mathrm{C}\right)$, the supernatant was collected, and TNF- $\alpha$ was measured using the cytokine-specific sandwich quantitative enzyme-linked immune-sorbent assay (ELISA) according to the manufacturer's instructions (TNF- $\alpha$ Duo Set and CCL2 Duo Set, R\&D Systems, USA). Cell viability was evaluated for all tested extracts, at the highest assayed concentration (250 $\mu \mathrm{g} / \mathrm{mL})$, by the MTT method [23], using untreated cells as reference for viability. Samples that gave cell viability higher than $90 \%$ were considered nontoxic for the THP1 cell line. The percentages of TNF- $\alpha$ and CCL2 inhibition were calculated by the ratio between the amount of mediators secreted by treated cells $(\mathrm{pg} / \mathrm{mL})$ and their baseline level (pg/mL) observed for solvent control (0.1\% DMSO). The inhibitory effects on TNF- $\alpha$ and CCL 2 release by LPSactivated THP-1 cells of the crude extracts and fractions were evaluated at $62.5,125$, and $250 \mu \mathrm{g} / \mathrm{mL}$. Dexamethasone (Sigma Aldrich, USA) was employed as positive control $(0.1 \mu \mathrm{M})$. For the assays, all samples were solubilized in RPMI medium containing $0.1 \%$ DMSO.

\subsection{DPPH (2,2-Diphenyl-1-picrylhydrazyl) Assay. The DPPH} radical scavenging assay was performed according to a previously reported method [24]. Briefly, samples solutions prepared in methanol $(0.5-7.5 \mu \mathrm{g} / \mathrm{mL})$ or pure methanol (control) were transferred to a 96-well microplate containing $70 \mu \mathrm{mol} / \mathrm{L}$ DPPH (Sigma Aldrich, USA) methanolic solution. The plate was shaken vigorously for $1 \mathrm{~min}$ and incubated in the dark for $30 \mathrm{~min}$, at $37^{\circ} \mathrm{C}$, following absorbance reading at 


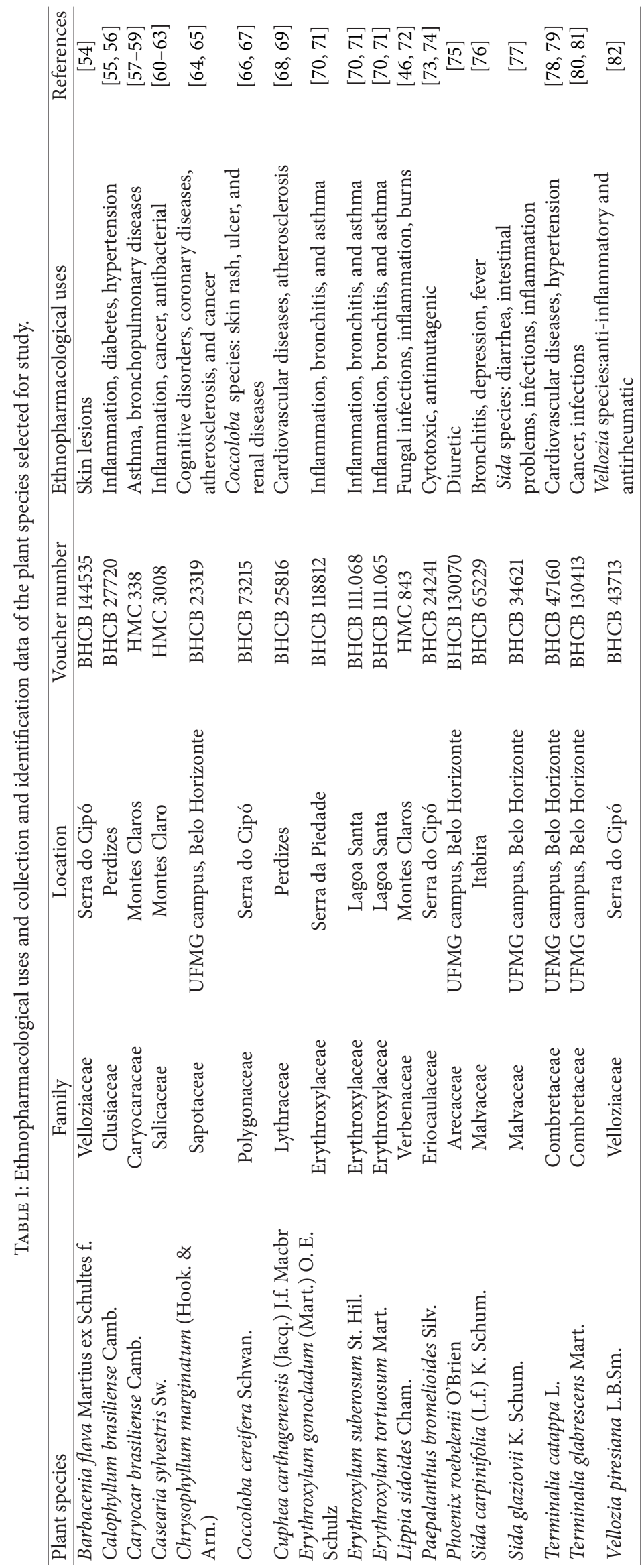


TABLE 2: Extraction yields and effect of the ethanol extracts from Brazilian plants on TNF- $\alpha$ and CCL2 release by LPS-stimulated THP-1 cells.

\begin{tabular}{|c|c|c|c|c|c|}
\hline Plant species & Plant part & Extraction yield (\%) & $\begin{array}{c}\text { Concentration } \\
(\mu \mathrm{g} / \mathrm{mL})\end{array}$ & $\begin{array}{c}\text { TNF- } \alpha \text { inhibition } \\
(\% \pm \mathrm{SD}, n=3)\end{array}$ & $\begin{array}{l}\text { CCL2 inhibition } \\
(\% \pm \mathrm{SD}, n=3)\end{array}$ \\
\hline \multirow{3}{*}{ Control } & & & LPS (100 ng) & $1030.4 \pm 2.7^{\mathrm{a}}$ & $1193.4 \pm 9.1^{\mathrm{a}}$ \\
\hline & & & DMSO (0.1\%) & $50.3 \pm 1.1^{\mathrm{a}}$ & $48.1 \pm 1.0^{\mathrm{a}}$ \\
\hline & & & $\begin{array}{c}\text { Dexamethasone } \\
(0.1 \mu \mathrm{M})\end{array}$ & $90.7 \pm 2.2^{*}$ & $87.7 \pm 0.6^{*}$ \\
\hline \multirow{3}{*}{ Barbacenia flava } & \multirow{3}{*}{ Aerial parts } & \multirow{3}{*}{8.3} & 62.5 & $27.5 \pm 7.5^{*}$ & $-16.3 \pm 6.9$ \\
\hline & & & 125 & $36.6 \pm 0.6^{*}$ & $-10.6 \pm 12.7$ \\
\hline & & & 250 & $45.4 \pm 12.9^{*}$ & $38.4 \pm 8.0^{*}$ \\
\hline \multirow{3}{*}{ Calophyllum brasiliense } & \multirow{3}{*}{ Aerial parts } & \multirow{3}{*}{8.0} & 62.5 & $-48.2 \pm 8.7$ & $-15.1 \pm 5.8$ \\
\hline & & & 125 & $-29.0 \pm 4.4$ & $-9.6 \pm 5.2$ \\
\hline & & & 250 & $-93.8 \pm 6.4$ & $23.7 \pm 3.4^{*}$ \\
\hline \multirow{3}{*}{ Caryocar brasiliense } & \multirow{3}{*}{ Leaves } & \multirow{3}{*}{39.4} & 62.5 & $19.4 \pm 0.5^{*}$ & $-15.5 \pm 5.8$ \\
\hline & & & 125 & $41.3 \pm 0.8^{*}$ & $-8.1 \pm 5.4$ \\
\hline & & & 250 & $61.1 \pm 3.9^{*}$ & $4.6 \pm 4.7$ \\
\hline \multirow{3}{*}{ Caryocar brasiliense } & \multirow{3}{*}{ Barks } & \multirow{3}{*}{29.0} & 62.5 & $17.6 \pm 4.2^{*}$ & $9.1 \pm 9.8$ \\
\hline & & & 125 & $43.7 \pm 2.0^{*}$ & $0.2 \pm 4.3$ \\
\hline & & & 250 & $62.5 \pm 4.3^{*}$ & $-2.2 \pm 6.4$ \\
\hline \multirow{3}{*}{ Casearia sylvestris } & \multirow{3}{*}{ Leaves } & \multirow{3}{*}{26.5} & 62.5 & $58.0 \pm 2.0^{*}$ & $12.1 \pm 5.6^{*}$ \\
\hline & & & 125 & $72.7 \pm 0.7^{*}$ & $92.7 \pm 0.9^{*}$ \\
\hline & & & 250 & $76.6 \pm 0.6^{*}$ & $95.5 \pm 0.1^{*}$ \\
\hline \multirow{3}{*}{ Chrysophyllum marginatum } & \multirow{3}{*}{ Aerial parts } & \multirow{3}{*}{14.7} & 62.5 & $49.0 \pm 1.4^{*}$ & $-19.2 \pm 5.1$ \\
\hline & & & 125 & $59.5 \pm 0.6^{*}$ & $-19.3 \pm 5.2$ \\
\hline & & & 250 & $79.1 \pm 0.4^{*}$ & $3.8 \pm 9.2$ \\
\hline \multirow{3}{*}{ Coccoloba cereifera } & \multirow{3}{*}{ Aerial parts } & \multirow{3}{*}{11.2} & 62.5 & $33.0 \pm 3.4^{*}$ & $-7.6 \pm 2.4$ \\
\hline & & & 125 & $49.5 \pm 0.8^{*}$ & $-8.2 \pm 0.4$ \\
\hline & & & 250 & $58.1 \pm 0.4^{*}$ & $-7.1 \pm 2.3$ \\
\hline & & & 62.5 & $25.7 \pm 0.6^{*}$ & $-43.3 \pm 2.4$ \\
\hline Cuphea carthagenensis & Aerial parts & 11.1 & 125 & $9.8 \pm 4.8$ & $-41.2 \pm 1.2$ \\
\hline & & & 250 & $15.7 \pm 3.0^{*}$ & $-14.0 \pm 6.6$ \\
\hline & & & 62.5 & $20.4 \pm 9.8^{*}$ & $-3.2 \pm 4.4$ \\
\hline Erythroxylum gonocladum & Leaves & 23.6 & 125 & $11.0 \pm 5.5$ & $-1.8 \pm 3.8$ \\
\hline & & & 250 & $25.5 \pm 16.6^{*}$ & $51.2 \pm 18.7^{*}$ \\
\hline & & & 62.5 & $-22.2 \pm 1.5$ & $-12.2 \pm 0.6$ \\
\hline Erythroxylum suberosum & Leaves & 18.6 & 125 & $-4.2 \pm 1.4$ & $-11.9 \pm 0.9$ \\
\hline & & & 250 & $28.2 \pm 7.5^{*}$ & $-12.9 \pm 1.9$ \\
\hline & & & 62.5 & $-49.3 \pm 13.6$ & $-29.5 \pm 4.8$ \\
\hline Erythroxylum tortuosum & Leaves & 27.2 & 125 & $-42.3 \pm 7.2$ & $-25.2 \pm 2.9$ \\
\hline & & & 250 & $-21.5 \pm 3.9$ & $15.0 \pm 19.8^{*}$ \\
\hline & & & 62.5 & $36.2 \pm 5.7^{*}$ & $30.7 \pm 6.5^{*}$ \\
\hline Lippia sidoides & Leaves & 18.0 & 125 & $41.6 \pm 2.4^{*}$ & $77.5 \pm 5.4^{*}$ \\
\hline & & & 250 & $42.1 \pm 0.1^{*}$ & $96.0 \pm 0.1^{*}$ \\
\hline & & & 62.5 & $1.5 \pm 5.7$ & $-58.7 \pm 9.5$ \\
\hline Paepalanthus bromelioides & Aerial parts & 7.7 & 125 & $14.5 \pm 2.2^{*}$ & $-51.2 \pm 6.8$ \\
\hline & & & 250 & $30.0 \pm 2.8^{*}$ & $-36.3 \pm 7.5$ \\
\hline & & & 62.5 & $28.0 \pm 1.1^{*}$ & $-2.1 \pm 9.8$ \\
\hline Phoenix roebelenii & Aerial parts & 14.7 & 125 & $7.0 \pm 3.80$ & $-10.3 \pm 9.2$ \\
\hline & & & 250 & $26.8 \pm 6.3^{*}$ & $37.5 \pm 3.8^{*}$ \\
\hline & & & 62.5 & $29.2 \pm 0.9^{*}$ & $-12.1 \pm 2.9$ \\
\hline Sida carpinifolia & Aerial parts & 8.7 & 125 & $1.1 \pm 3.1$ & $-9.8 \pm 2.4$ \\
\hline & & & 250 & $69.2 \pm 0.6^{*}$ & $-8.9 \pm 4.6$ \\
\hline
\end{tabular}


TABLE 2: Continued.

\begin{tabular}{|c|c|c|c|c|c|}
\hline Plant species & Plant part & Extraction yield (\%) & $\begin{array}{c}\text { Concentration } \\
(\mu \mathrm{g} / \mathrm{mL})\end{array}$ & $\begin{array}{c}\text { TNF- } \alpha \text { inhibition } \\
(\% \pm \mathrm{SD}, n=3)\end{array}$ & $\begin{array}{l}\text { CCL2 inhibition } \\
(\% \pm \mathrm{SD}, n=3)\end{array}$ \\
\hline \multirow{3}{*}{ Sida glaziovii } & \multirow{3}{*}{ Aerial parts } & \multirow{3}{*}{10.5} & 62.5 & $39.2 \pm 1.2^{*}$ & $-46.1 \pm 1.4$ \\
\hline & & & 125 & $39.6 \pm 4.2^{*}$ & $-44.3 \pm 3.1$ \\
\hline & & & 250 & $58.0 \pm 3.9^{*}$ & $-29.1 \pm 3.1$ \\
\hline \multirow{3}{*}{ Terminalia catappa } & \multirow{3}{*}{ Leaves } & \multirow{3}{*}{6.7} & 62.5 & $-51.0 \pm 9.3$ & $-33.0 \pm 7.1$ \\
\hline & & & 125 & $-39.3 \pm 9.2$ & $-31.0 \pm 5.3$ \\
\hline & & & 250 & $73.4 \pm 0.6^{*}$ & $41.6 \pm 14.9^{*}$ \\
\hline \multirow{3}{*}{ Terminalia glabrescens } & \multirow{3}{*}{ Leaves } & \multirow{3}{*}{7.5} & 62.5 & $48.3 \pm 1.8^{*}$ & $3.7 \pm 1.1$ \\
\hline & & & 125 & $52.3 \pm 1.8^{*}$ & $10.3 \pm 2.1$ \\
\hline & & & 250 & $59.1 \pm 1.6^{*}$ & $57.2 \pm 2.3^{*}$ \\
\hline \multirow{3}{*}{ Vellozia piresiana } & \multirow{3}{*}{ Leaves } & \multirow{3}{*}{9.8} & 62.5 & $15.7 \pm 3.3^{*}$ & $-8.6 \pm 6.2$ \\
\hline & & & 125 & $-5.8 \pm 5.6$ & $0.9 \pm 5.2$ \\
\hline & & & 250 & $15.0 \pm 1.4^{*}$ & $46.2 \pm 9.5^{*}$ \\
\hline
\end{tabular}

${ }^{\mathrm{a}}$ Inflammatory mediators production (absolute values in $\mathrm{pg} / \mathrm{mL}$ ).

${ }^{*}$ Differences in the release of TNF- $\alpha$ and CCL-2 elicited by the extracts were analyzed by one-way ANOVA followed by multiple comparisons of NewmanKeuls. In each extract, $*$ indicates significant inhibition of TNF- $\alpha$ or CCL-2 release in comparison to LPS-stimulated cells $(P<0.05)$. Dexamethasone $(0.1 \mu \mathrm{M})$ was employed as positive control.

the wavelength of $517 \mathrm{~nm}$, using a multiwell scanning spectrophotometer (Tecan Infinity M200, Switzerland). The radical scavenging capacity (expressed as percentage) was calculated as the rate between $\left(\mathrm{Abs}_{\text {control }}-\mathrm{Abs}_{\text {sample }}\right) / \mathrm{Abs}_{\text {control }} \times$ 100. Rutin (Sigma Aldrich, USA) was employed as positive control.

2.4. Statistical Analysis. The $\mathrm{IC}_{50}$ values were determined for the extracts which inhibited more significantly the production of TNF- $\alpha$ and CCL2 by THP-1 cells, as well as for all extracts evaluated in the DPPH radical scavenging assay. In each case, $\mathrm{IC}_{50}$ values were calculated using at least five concentrations and represent the mean \pm SD for $n=5$. The inhibition values of inflammatory mediators were compared to the control cells stimulated with LPS using analysis of variance (one-way ANOVA) followed by Newman-Keuls post test. For the DPPH assay, the data were compared by oneway ANOVA, followed by Tukey's test [25], representing the mean $\pm \mathrm{SD}$ for $n=5$. $P$ values less than $0.05(P<0.05)$ were considered significant.

\section{Results}

3.1. Effects on LPS-Induced Proinflammatory Mediators TNF$\alpha$ and CCL2. The ethanol extracts of the selected plants were initially evaluated on THP-1 cells at $250 \mu \mathrm{g} / \mathrm{mL}$ to investigate cellular toxicity. All extracts produced cell viability above $90 \%$, being considered noncytotoxic and evaluated in the subsequent experiments. The inhibition of TNF- $\alpha$ and CCL2 release by LPS-stimulated THP-1 cells was assayed at three concentrations to investigate concentration-dependent response in the biological effect.

Among the 19 extracts assayed, those of Caryocar brasiliense (barks and leaves), Casearia sylvestris, Chrysophyllum marginatum, Coccoloba cereifera, and Terminalia glabrescens significantly inhibited TNF- $\alpha$ production by
THP-1 cells in a concentration-dependent manner (Table 2). Other extracts were active at specific concentrations, but the response could not be characterized as concentrationdependent, including Barbacenia flava, Lippia sidoides, Sida carpinifolia, Sida glaziovii, and Terminalia catappa. On their turn, the extracts of Calophyllum brasiliense and Erythroxylum tortuosum increased TNF- $\alpha$ level at all assayed concentrations, suggesting that they may have proinflammatory effects. The remaining extracts showed variable responses, either enhancing or decreasing TNF- $\alpha$ levels, depending on the assayed concentration, suggesting nonspecific responses (Table 2).

The most active extracts had their $\mathrm{IC}_{50}$ values determined and were found to be in the range of $124.0 \pm 1.0$ to $224.0 \pm$ $1.0 \mu \mathrm{g} / \mathrm{mL}$, respectively, for Casearia sylvestris and Caryocar brasiliense leaves (Table 3). The extracts of Caryocar brasiliense (barks) and Chrysophyllum marginatum did not reach the plateau for $\mathrm{IC}_{50}$ determination, indicating that higher concentrations were needed.

Among the 19 extracts evaluated, only those of Lippia sidoides and Terminalia glabrescens inhibited significantly CCL2 release by LPS-stimulated THP-1 cells in a concentration-dependent manner (Table 2). Lippia sidoides reduced CCL2 production by $96.0 \pm 0.1 \%$ when tested at $250 \mu \mathrm{g} / \mathrm{mL}$, indicating potency higher than the positive control dexamethasone. Casearia sylvestris was also very potent and had a very steep inhibition curve as inhibition of chemokine production was already maximal at $125 \mu \mathrm{g} / \mathrm{mL}$. Most of the assayed extracts elicited CCL2 inhibition at one single concentration, mostly at $250 \mu \mathrm{g} / \mathrm{mL}$, whereas increase in chemokine concentration was observed at the medium and intermediate concentrations. The $\mathrm{IC}_{50}$ values were determined only for the extracts of Lippia sidoides (64.2 \pm $1.0 \mu \mathrm{g} / \mathrm{mL})$ and Terminalia glabrescens $(189.4 \pm 1.0 \mu \mathrm{g} / \mathrm{mL})$, since the remaining 17 extracts did not inhibit CCL2 release in a concentration-dependent manner and the responses were very steep for Casearia sylvestris. 
TABLE 3: $\mathrm{IC}_{50}$ values determined for selected extracts on in vitro inhibition of inflammatory mediators and radical scavenging activity.

\begin{tabular}{lcccc}
\hline Plant species & TNF- $\alpha(\mu \mathrm{g} / \mathrm{mL} \pm$ SD $)$ & CCL2 $(\mu \mathrm{g} / \mathrm{mL} \pm \mathrm{SD})$ & ${ }^{*} \mathrm{DPPH}$ assay $(\mu \mathrm{g} / \mathrm{mL} \pm$ SD $)$ & Inhibition ratio extract/rutin \\
\hline Barbacenia flava & $>250$ & $>250$ & $6.61 \pm 1.7^{\mathrm{f}}$ & 0.77 \\
Calophyllum brasiliense & $>250$ & $>250$ & $6.03 \pm 2.2^{\mathrm{g}}$ & 0.70 \\
Caryocar brasiliense barks & $>500$ & $>250$ & $6.13 \pm 1.5^{\mathrm{g}}$ & 0.71 \\
Caryocar brasiliense leaves & $224.0 \pm 1.0$ & $>250$ & $3.01 \pm 1.0^{\mathrm{k}}$ & 0.35 \\
Casearia sylvestris & $124.0 \pm 1.0$ & $>250$ & $5.70 \pm 2.1^{\mathrm{gh}}$ & 0.66 \\
Coccoloba cereifera & $194.3 \pm 1.1$ & $>250$ & $4.12 \pm 1.4^{\mathrm{i}}$ & 0.48 \\
Cuphea carthagenensis & $>250$ & $>250$ & $5.40 \pm 1.6^{\mathrm{h}}$ & 0.62 \\
Chrysophyllum marginatum & $>500$ & $>250$ & $6.93 \pm 1.3^{\mathrm{f}}$ & 0.80 \\
Erythroxylum gonocladum & $>250$ & $>250$ & $8.81 \pm 1.0^{\mathrm{cd}}$ & 1.02 \\
Erythroxylum suberosum & $>250$ & $>250$ & $5.72 \pm 2.0^{\mathrm{gh}}$ & 0.66 \\
Erythroxylum tortuosum & $>250$ & $>250$ & $6.55 \pm 1.0^{\mathrm{f}}$ & $0.76 \pm 1.8^{\mathrm{e}}$ \\
Lippia sidoides & $>500$ & $7.3 \pm 1.0$ & $3.62 \pm 1.4^{\mathrm{j}}$ & 0.88 \\
Paepalanthus bromelioides & $>250$ & $>250$ & $6.56 \pm 2.0^{\mathrm{f}}$ & 0.42 \\
Phoenix roebelenii & $>250$ & $>250$ & $13.23 \pm 3.9^{\mathrm{a}}$ & 0.76 \\
Sida carpinifolia & $>250$ & $>250$ & $5.46 \pm 2.4^{\mathrm{h}}$ & 1.54 \\
Sida glaziovii & $>250$ & $>250$ & $6.12 \pm 1.9^{\mathrm{g}}$ & 0.63 \\
Terminalia catappa & $>250$ & $>250$ & $10.66 \pm 1.9^{\mathrm{b}}$ & 0.71 \\
Terminalia glabrescens & $153.5 \pm 1.1$ & $>250$ & $7.50 \pm 4.2^{\mathrm{e}}$ & 1.24 \\
Vellozia piresiana & $>250$ & $\mathrm{ND}$ & $8.58 \pm 1.0^{\mathrm{d}}$ & 0.84 \\
Rutin & $\mathrm{ND}$ & & 1
\end{tabular}

ND: not determined.

${ }^{*} \mathrm{IC}_{50}$ values were analyzed by one-way ANOVA, followed by Tukey's test. Values with different letters differ statistically from each other according to Tukey's test $(P<0.05)$.

The extracts which elicited potent inhibition of the proinflammatory mediators, respectively, Caryocar brasiliense (leaves), Casearia sylvestris, and Coccoloba cereifera for TNF$\alpha$, Lippia sidoides for CCL2, and Terminalia glabrescens for both, were fractionated by partition between immiscible solvents and the resulting fractions had their anti-inflammatory effect assayed. In general, the anti-TNF- $\alpha$ activity was mainly found in the ethyl acetate and water fractions (Figure 1), whereas low polarity fractions of Terminalia glabrescens were also active. Interestingly, all fractions of this species promoted significant CCL2 inhibition, mostly the low and medium polar fractions (Figure 2). A similar result was found for Lippia sidoides, whose CCL2 activity concentrated in the hexane, DCM, and EtOAc fractions (Figure 2). These findings suggest that CCL2 inhibition is probably elicited by low and medium polar compounds, whereas high polar constituents may account for the anti-TNF- $\alpha$ effect of the assayed extracts.

3.2. Antioxidant Activity. The antioxidant activity of the extracts was investigated in vitro using the DPPH assay and the $\mathrm{IC}_{50}$ values are listed in Table 3 . The ratio between the $\mathrm{IC}_{50}$ values of the extracts and rutin (positive control) was calculated and allowed categorizing the extracts as high (ratio $\leq 0.5$ ), intermediate (ratio between 0.51 and 0.99 ), and low (ratio $\geq 1$ ) active. Based on this ranking, the highest DPPH free radical scavenging activities were elicited by the extracts of Caryocar brasiliense (leaves), Coccoloba cereifera, and Paepalanthus bromelioides. On their turn, the extracts of Terminalia glabrescens, Erythroxylum gonocladum, and Sida carpinifolia showed antioxidant properties less potent than rutin, whereas the other extracts were active, with $\mathrm{IC}_{50}$ values lower than rutin. Interestingly, among the three extracts with the highest radical scavenging activity, those of Caryocar brasiliensis and Coccoloba cereifera also elicited significant inhibition of TNF- $\alpha$, suggesting a correlation between the activities, which was also found for other active extracts. On the other hand, none of the extracts with low $\mathrm{IC}_{50}$ values in the DPPH assay inhibited CCL2 significantly. It should be also mentioned that the extract of Terminalia glabrescens significantly inhibited both proinflammatory mediators, but its antioxidant activity was lower than rutin. This finding suggests that compounds other than polyphenols may account for the anti-inflammatory properties of this extract.

\section{Discussion}

TNF- $\alpha$ is a potent proinflammatory cytokine detected in high concentrations in the synovial cavity of patients with rheumatoid arthritis [26]. It is secreted by activated monocytes and subsequently activates other cell types in the blood vessel and thus initiates/promotes the progression of atherosclerosis [27]. CCL2 is a chemokine responsible for monocytes and macrophages migration to inflammatory sites, which also has a direct effect on angiogenesis [28-30]. Increased levels of CCL2 were found to correlate with complications associated with atherosclerosis, including ischemic stroke, myocardial infarction, and cardiovascular disease mortality [31-33]. 


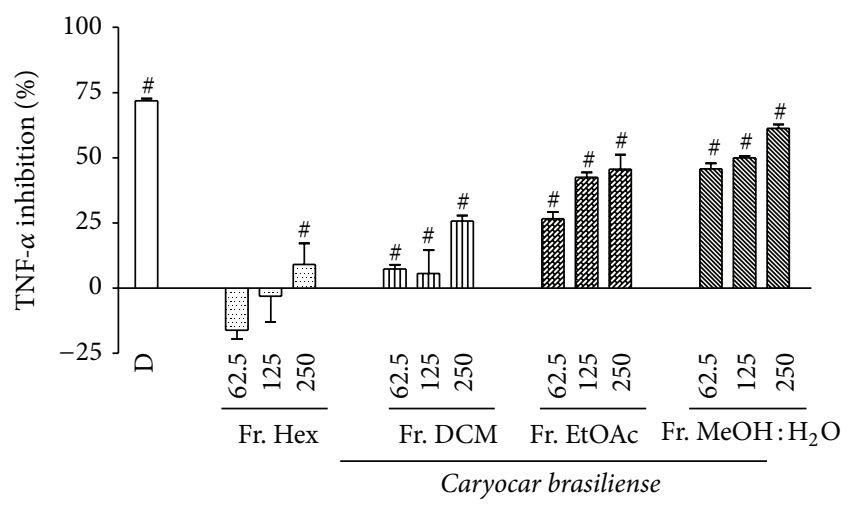

(a)

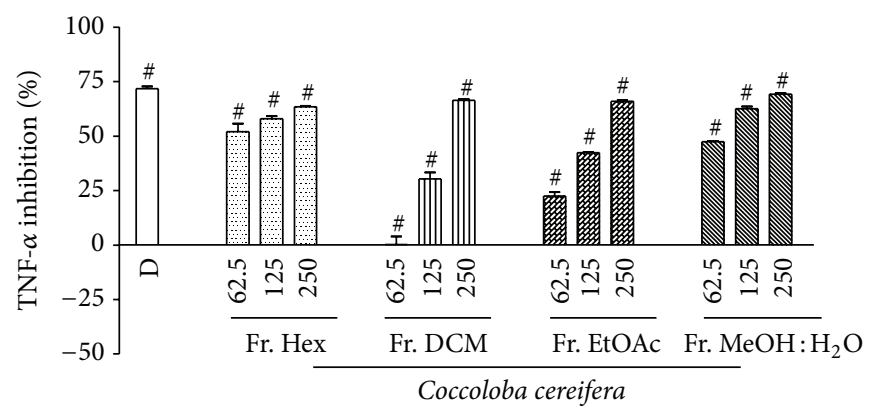

(b)

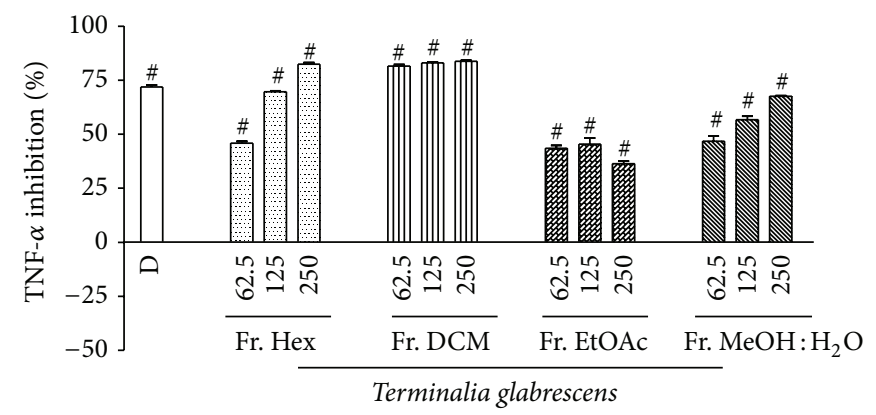

(c)

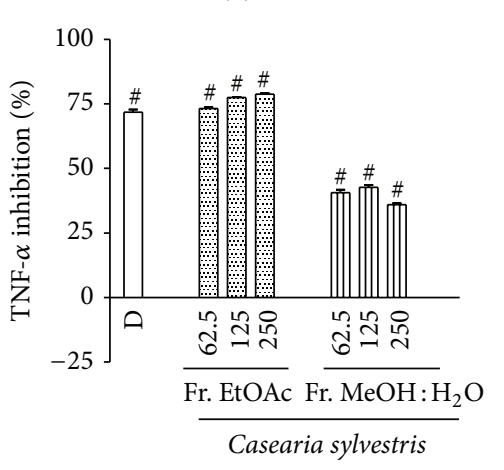

(d)

FIGURE 1: Effects of the fractions from Brazilian plants on TNF- $\alpha$ release by LPS-activated THP-1 cells, assayed at different concentrations (62.5, 125, and $250 \mu \mathrm{g} / \mathrm{mL}$ ): (a) Caryocar brasiliense, (b) Coccoloba cereifera, (c) Terminalia glabrescens, and (d) Casearia sylvestris. Data represent the mean inhibition $(\% \pm$ SD) from three separate experiments. Differences in TNF- $\alpha$ release elicited by the fractions were analyzed by oneway ANOVA followed by multiple comparisons of Newman-Keuls. In each fraction, \# indicates significant inhibition of TNF- $\alpha$ release in comparison to LPS-stimulated cells $(P<0.05)$. $\mathrm{D}=$ dexamethasone $(0.1 \mu \mathrm{M}$; positive control). TNF- $\alpha$ mean value of LPS-stimulated THP-1 cells was $1092.49 \pm 4.87 \mathrm{pg} / \mathrm{mL}$ and the basal level was $52.54 \pm 1.21 \mathrm{pg} / \mathrm{mL}$.

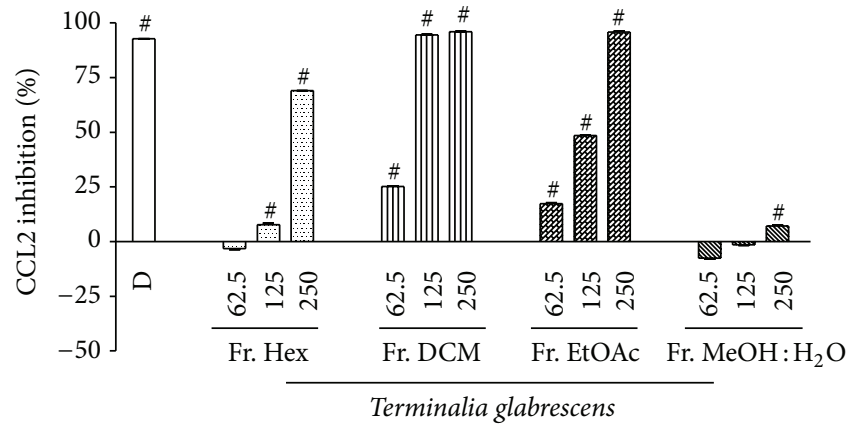

(a)

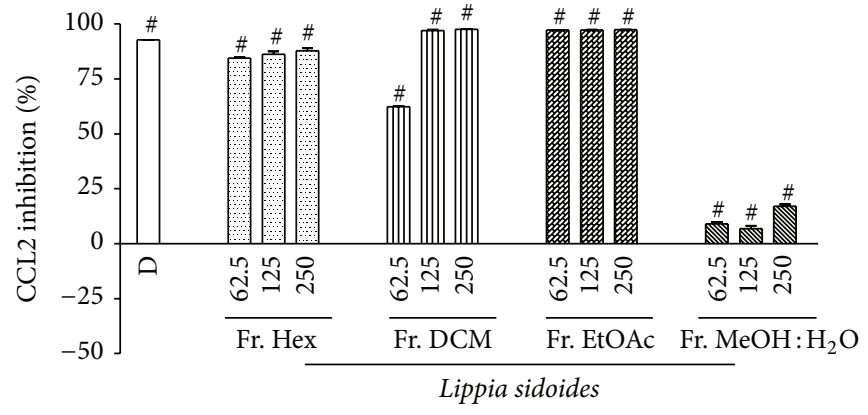

(b)

FIGURE 2: Effects of the fractions from Brazilian plants on CCL2 release in LPS-activated THP-1 cells, assayed at different concentrations (62.5, 125, and $250 \mu \mathrm{g} / \mathrm{mL}$ ): (a) Terminalia glabrescens and (b) Lippia sidoides. Data represent the mean inhibition (\% \pm SD) from three separate experiments. Differences in CCL2 release elicited by the fractions were analyzed by one-way ANOVA followed by multiple comparisons of Newman-Keuls. In each fraction, \# indicates significant inhibition of CCL2 release in comparison to LPS-stimulated cells $(P<0.05)$. $\mathrm{D}=$ dexamethasone $(0.1 \mu \mathrm{M}$; positive control). CCL2 mean value of LPS-stimulated cells was $1388.15 \pm 3.43 \mathrm{pg} / \mathrm{mL}$ and the basal level was $58.97 \pm 0.69 \mathrm{pg} / \mathrm{mL}$. 
There is much evidence to suggest the participation of inflammatory processes in the basis of hypertension, suggesting a link between inflammation and hypertension. Moreover, vascular inflammation plays an important role in hypertension genesis and progression, resulting in aggravation of atherosclerosis $[11,12]$. Previous studies have demonstrated high levels of CCL2 in patients with arterial hypertension, as well as increased levels of TNF- $\alpha$ on DOCA-salt models $[34,35]$. Therefore, the identification of TNF- $\alpha$ and CCL2 antagonists from natural sources would represent a new approach for the management of various chronic inflammatory conditions, including rheumatoid arthritis and cardiovascular diseases like arthrosclerosis $[26,36]$.

The screening of plant extracts with anti-inflammatory properties on a cell-based assay platform, targeting key inflammatory mediators as TNF- $\alpha$ and CCL2, is recognized nowadays as a valid strategy to select plant species for phytochemical studies $[20,21]$. Most of the reported screenings have been carried out at one single concentration. This approach impairs to investigate concentration-dependent response in the biological effect and consequently to eliminate the extracts with unspecific effect for further studies. Therefore, in this study we assayed the extracts at three levels and the most active ones had their $\mathrm{IC}_{50}$ values determined.

The plants described here were selected based on their traditional use to treat inflammatory and/or cardiovascular diseases by the species themselves or others of the same genus. Respectively, six and two extracts among a total of 19 inhibited significantly TNF- $\alpha$ and CCL 2 release by LPSstimulated THP-1 cells, in a concentration-dependent manner, indicating the validity of the approach employed for plant selection. There are not many reports on the screening of plant extract targeting these inflammatory mediators. Among four plant extracts screened by Nishijima [37], only Rhamnidium elaeocarpum elicited significant anti-TNF- $\alpha$ activity in LPS-stimulated murine peritoneal macrophages, but at higher concentration ( $2 \mathrm{mg} / \mathrm{mL} ; 48.86 \%$ inhibition) than that employed in our study. On its turn, Hypericum triquetrifolium inhibited TNF- $\alpha$ release by LPS-stimulated THP-1 cells in a concentration-dependent manner, in a similar range of concentrations reported here [38].

Other studies disclosed plant extracts with similar or even higher TNF- $\alpha$ inhibitory activity. Extracts of different polarities from nine medicinal plants from Thailand showed antiTNF- $\alpha$ effects in LPS-stimulated human monocytes, with $\mathrm{IC}_{50}$ values ranging from 0.28 to $>50 \mu \mathrm{g} / \mathrm{mL}$ [21]. In another study with 64 medicinal plants from South-East Spain, extracts of Bupleurum fruticosum, Chamaespartium tridentatum, Genista ramosissima, Helichrysum stoechas, Mercurialis tomentosa, Ononis ramosissima, Peganum harmala, Picnomon acarna, Retama sphaerocarpa, and Santolina viscosa were active at inhibiting TNF- $\alpha$ at $10 \mu \mathrm{g} / \mathrm{mL}$ in LPS-stimulated human monocytes [20].

Regarding the anti-inflammatory effect on CCL2, our study revealed two species, Casearia sylvestris and Lippia sidoides, with inhibition rates above $95 \%$ at the highest tested concentration. The effect of other plant extracts or isolated compounds on this chemokine has been previously investigated in THP-1 cells. The administration of a decoction from
Rehmannia glutinosa rhizomes to THP-1 cells treated with AGEs downregulated the expression of proinflammatory genes, including CCL2 mRNA levels, when tested at 500 and $1000 \mu \mathrm{g} / \mathrm{mL}$ [39]. Similar results were reported for alcoholic and aqueous extracts from Ocimum sanctum leaves, which markedly inhibited the expression of proinflammatory genes, CCL2 marker including, when assayed at $1000 \mu \mathrm{g} / \mathrm{mL}$ in LPSstimulated THP-1 cells [27]. On its turn, catalpol, an iridoid glucoside isolated from the roots of Rehmannia glutinosa, reduced the expression of proinflammatory mediators such as CCL2, TNF- $\alpha$, iNOS, and RAGE, when administrated at 300 and $500 \mu \mathrm{g} / \mathrm{mL}$ to AGE-stimulated THP-1 cells [40]. These data demonstrate unequivocally the anti-inflammatory potential of the plant species disclosed in the present study, which inhibited CCL2 at much lower concentrations.

The HPLC-DAD fingerprints recorded for the most active extracts (Caryocar brasiliense leaves, Casearia sylvestris, Coccoloba cereifera, Terminalia glabrescens, and Lippia sidoides) indicate they are majorly composed by polar compounds, mainly polyphenols like flavonoids and proanthocyanidins (data not shown). Excepting Coccoloba cereifera and Lippia sidoides, the occurrence of flavonoids and proanthocyanidins has been described for all the above-mentioned species [4144]. On the other hand, flavonoids have been isolated from other Coccoloba and Lippia species $[45,46]$.

Some of the active species reported here have had their anti-inflammatory effect previously investigated, mostly for their essential oils, such as Lippia sidoides [47, 48], Caryocar brasiliense [49], and Casearia sylvestris [50]. The antiinflammatory effect of Terminalia glabrescens and Coccoloba cereifera is reported here for the first time.

The obtained results suggest that polar compounds may be responsible for the TNF- $\alpha$ inhibition elicited by the species, since the activity was concentrated in the ethyl acetate and methanolic aqueous fractions. In general, these fractions showed higher inhibition rates than the crude extracts, indicating that the anti-inflammatory effect is potentiated by fractionation. On the other hand, higher CCL2 inhibitory activities were observed for the low polar fractions. This finding indicates that different classes of compounds may account for the inhibition of TNF- $\alpha$ and CCL2, suggesting a selective effect.

Significant DPPH scavenging activity was observed for all tested extracts, probably due to the presence of phenolic compounds, whose antioxidant properties have been extensively reported using in vivo and in vitro assays [51, 52]. ROS seems to play a complex role in inflammation. According to Alessandri and coworkers [2], a small concentration of ROS can promote an improvement in the resolution of inflammatory processes. On the other hand, the uncontrolled increase of ROS generation can initiate and perpetuate inflammatory cascades, causing an additional damage through the regulation of genes involved in inflammatory responses [15]. Therefore, a temporal control of ROS generation can determine their action as pro- or anti-inflammatory agents [2]. Considering that rheumatoid arthritis is a chronic disease, antioxidant properties allied to TNF- $\alpha$ and CCL2 inhibition might be beneficial for inflammation resolution. 
Taken together, our results allowed identifying four extracts with selective anti-inflammatory response, three with marked anti-TNF- $\alpha$ activity and one with CCL2 inhibiting effect, in addition to one extract active against both mediators. Interestingly, the active extracts showed more selectivity for TNF- $\alpha$, whereas those inhibiting CCL2 in a greater extension also presented anti-TNF- $\alpha$ effect. A selective anti-TNF- $\alpha$ effect is desirable for developing new antirheumatic drugs, since the administration of CCL2 monoclonal antibody to patients with rheumatoid arthritis did not ameliorate the disease and even aggravated the symptoms at higher doses. The effect was related to a dramatic increase of antibody-complexed CCL2 levels in peripheral blood $[33,53]$. On the other hand, selective CCL2 inhibition indicates a new approach for treating atherosclerosis.

\section{Conclusion}

Plant screening directed towards a disease specific mediator is undoubtedly a further step in the quest for new active natural products. Some of the extracts evaluated in this study were able to reduce TNF- $\alpha$ release selectively, whereas others inhibited preferably CCL2, pointing out the first group of plants as potential sources of compounds for management of rheumatoid arthritis, whereas the second ones would be more suited for the treatment of cardiovascular diseases like atherosclerosis. Moreover, all assayed extracts showed radical scavenging properties, which may have additional beneficial effects for treating inflammation related diseases.

\section{Conflict of Interests}

The authors declare that there is no conflict of interests regarding the publication of this paper.

\section{Acknowledgments}

The authors acknowledge FAPEMIG and CNPq/Brazil for the financial support along with research (Fernão C. Braga and Mauro M. Teixeira) and undergraduate (Luciano C. Castro) fellowships. CAPES/Brazil is acknowledged for a Ph.D. fellowship (Grasielle S. Gusman). This work received financial support from the European Community's Seventh Framework Programme [FP7-2007-2013] under Grant Agreement HEALTH-F4-2011-281608. It also received funding from the National Institute of Science and Technology in Dengue (CNpq/Brazil).

\section{References}

[1] T. Van-Assche, V. Huygelen, M. J. Crabtree, and C. Antoniades, "Gene therapy targeting inflammation in atherosclerosis," Current Pharmaceutical Design, vol. 17, no. 37, pp. 4210-4223, 2011.

[2] A. L. Alessandri, L. P. Sousa, C. D. Lucas, A. G. Rossi, V. Pinho, and M. M. Teixeira, "Resolution of inflammation: mechanisms and opportunity for drug development," Pharmacology \& Therapeutics, vol. 139, no. 2, pp. 189-212, 2013.

[3] L. Klareskog, A. I. Catrina, and S. Paget, "Rheumatoid arthritis," The Lancet, vol. 373, no. 9664, pp. 659-672, 2009.
[4] D. L. Scott and G. H. Kingsley, "Tumor necrosis factor inhibitors for rheumatoid arthritis," The New England Journal of Medicine, vol. 355, no. 7, pp. 704-712, 2006.

[5] M. Croft, C. A. Benedict, and C. F. Ware, "Clinical targeting of the TNF and TNFR superfamilies," Nature Reviews Drug Discovery, vol. 12, no. 2, pp. 147-168, 2013.

[6] T. Bongartz, A. J. Sutton, M. J. Sweeting, I. Buchan, E. L. Matteson, and V. Montori, "Anti-TNF antibody therapy in rheumatoid arthritis and the risk of serious infections and malignancies: systematic review and meta-analysis of rare harmful effects in randomized controlled trials," The Journal of the American Medical Association, vol. 295, no. 19, pp. 2275$2285,2006$.

[7] S. R. Bernatsky, A. E. Clarke, M. A. Petri et al., "Further defining cancer risk in systemic lupus: updated results in an expanded international multi-centre cohort," Arthritis \& Rheumatism, vol. 62, p. S731, 2010.

[8] M. Usui, K. Egashira, H. Tomita et al., "Important role of local angiotensin II activity mediated via type I receptor in the pathogenesis of cardiovascular inflammatory changes induced by chronic blockade of nitric oxide synthesis in rats," Circulation, vol. 101, no. 3, pp. 305-310, 2000.

[9] Y. J. Ko, J.-S. Lee, B. C. Park, H. M. Shin, and J.-A. Kim, "Inhibitory effects of Zoagumhwan water extract and berberine on angiotensin II-induced monocyte chemoattractant protein (MCP)-1 expression and monocyte adhesion to endothelial cells," Vascular Pharmacology, vol. 47, no. 2-3, pp. 189-196, 2007.

[10] A. Ueda, Y. Ishigatsubo, T. Okubo, and T. Yoshimura, "Transcriptional regulation of the human monocyte chemoattractant protein-1 gene: cooperation of two NF- $\kappa$ B sites and NF- $\kappa \mathrm{B} / \mathrm{Rel}$ subunit specificity," Journal of Biological Chemistry, vol. 272, no. 49, pp. 31092-31099, 1997.

[11] P. Libby, P. M. Ridker, and A. Maseri, "Inflammation and atherosclerosis," Circulation, vol. 105, no. 9, pp. 1135-1143, 2002.

[12] V. Gupta, S. Sachdeva, A. S. Khan, and S. F. Haque, "Endothelial dysfunction and inflammation in different stages of essential hypertension," Saudi Journal of Kidney Diseases and Transplantation, vol. 22, no. 1, pp. 97-103, 2011.

[13] S. P. Desai, L. L. Henry, S. D. Holmes et al., "Strict versus liberal target range for perioperative glucose in patients undergoing coronary artery bypass grafting: a prospective randomized controlled trial," The Journal of Thoracic and Cardiovascular Surgery, vol. 143, no. 2, pp. 318-325, 2012.

[14] E. J. Cho, T. Yokozawa, D. Y. Rhyu, S. C. Kim, N. Shibahara, and J. C. Park, "Study on the inhibitory effects of Korean medicinal plants and their main compounds on the 1,1-diphenyl-2picrylhydrazyl radical," Phytomedicine, vol. 10, no. 6-7, pp. 544$551,2003$.

[15] V. Cachofeiro, M. Miana, N. de las Heras et al., "Inflammation: a link between hypertension and atherosclerosis," Current Hypertension Reviews, vol. 5, no. 1, pp. 40-48, 2009.

[16] F. Lopes, F. M. Coelho, V. V. Costa et al., "Resolution of neutrophilic inflammation by $\mathrm{H}_{2} \mathrm{O}_{2}$ in antigen-induced arthritis," Arthritis \& Rheumatism, vol. 63, no. 9, pp. 2651-2660, 2011.

[17] J. B. Calixto, "Twenty-five years of research on medicinal plants in Latin America: a personal view," Journal of Ethnopharmacology, vol. 100, no. 1-2, pp. 131-134, 2005.

[18] H. S. Falcão, I. O. Lima, V. L. dos Santos et al., "Review of the plants with anti-inflammatory activity studied in Brazil," Brazilian Journal of Pharmacognosy, vol. 15, pp. 381-391, 2005.

[19] C. Desmarchelier, "Neotropics and natural ingredients for pharmaceuticals: why isn't south American biodiversity on the crest of the wave?" Phytotherapy Research, vol. 24, no. 6, pp. 791799, 2010. 
[20] P. Bremner, D. Rivera, M. A. Calzado et al., "Assessing medicinal plants from South-Eastern Spain for potential anti-inflammatory effects targeting nuclear factor-Kappa B and other proinflammatory mediators," Journal of Ethnopharmacology, vol. 124, no. 2, pp. 295-305, 2009.

[21] N. Siriwatanametanon, B. L. Fiebich, T. Efferth, J. M. Prieto, and M. Heinrich Michael, "Traditionally used Thai medicinal plants: in vitro anti-inflammatory, anticancer and antioxidant activities," Journal of Ethnopharmacology, vol. 130, no. 2, pp. 196-207, 2010.

[22] T. Weiss, I. Shalit, H. Blau et al., "Anti-inflammatory effects of moxifloxacin on activated human monocytic cells: inhibition of NF- $\kappa \mathrm{B}$ and mitogen-activated protein kinase activation and of synthesis of proinflammatory cytokines," Antimicrobial Agents and Chemotherapy, vol. 48, no. 6, pp. 1974-1982, 2004.

[23] M. Ferrari, M. C. Fornasiero, and A. M. Isetta, "MTT colorimetric assay for testing macrophage cytotoxic activity in vitro," Journal of Immunological Methods, vol. 131, no. 2, pp. 165-172, 1990.

[24] K. S. Farias, T. S. N. Santos, M. R. A. B. Paiva et al., "Antioxidant properties of species from the Brazilian cerrado by different assays," Brazilian Journal of Medicinal Plants, vol. 15, no. 4, pp. 520-528, 2013.

[25] J. W. Tukey, Exploratory Data Analysis, Addison-Wesley, Reading, Mass, USA, 1977.

[26] E. Bressan, F. de Queiroz Cunha, and C. R. Tonussi, "Contribution of TNF $\alpha$, IL- $1 \beta$ and CINC-1 for articular incapacitation, edema and cell migration in a model of LPS-induced reactive arthritis," Cytokine, vol. 36, no. 1-2, pp. 83-89, 2006.

[27] S. S. Choudhury, L. Bashyam, N. Manthapuram, P. Bitla, P. Kollipara, and S. D. Tetali, "Ocimum sanctum leaf extracts attenuate human monocytic (THP-1) cell activation," Journal of Ethnopharmacology, vol. 154, no. 1, pp. 148-155, 2014.

[28] H. Xue, R. M. Aziz, and N. Sun, "Inhibition of cellular transformation by berry extracts," Carcinogenesis, vol. 22, pp. 351-356, 2001.

[29] R. D. Loberg, C. Ying, M. Craig et al., "Targeting CCL2 with systemic delivery of neutralizing antibodies induces prostate cancer tumor regression in vivo," Cancer Research, vol. 67, no. 19, pp. 9417-9424, 2007.

[30] M. Atalay, G. Gordillo, S. Roy et al., "Anti-angiogenic property of edible berry in a model of hemangioma," FEBS Letters, vol. 544, no. 1-3, pp. 252-257, 2003.

[31] A. Arakelyan, J. Petrkova, Z. Hermanova, A. Boyajyan, J. Lukl, and M. Petrek, "Serum levels of the MCP-1 chemokine in patients with ischemic stroke and myocardial infarction," Mediators of Inflammation, vol. 2005, no. 3, pp. 175-179, 2005.

[32] L. Piemonti, G. Calori, G. Lattuada et al., "Association between plasma monocyte chemoattractant protein-1 concentration and cardiovascular disease mortality in middle-aged diabetic and nondiabetic individuals," Diabetes Care, vol. 32, no. 11, pp. 21052110, 2009.

[33] A. A. Elmarakby, J. E. Quigley, J. D. Imig, J. S. Pollock, and D. M. Pollock, "TNF- $\alpha$ inhibition reduces renal injury in DOCA-salt hypertensive rats," American Journal of Physiology: Regulatory Integrative and Comparative Physiology, vol. 294, no. 1, pp. R76R83, 2008.

[34] J. Panee, "Monocyte Chemoattractant Protein 1 (MCP-1) in obesity and diabetes," Cytokine, vol. 60, no. 1, pp. 1-12, 2012.

[35] A. Antonelli, P. Fallahi, S. M. Ferrari et al., "High serum levels of CXC (CXCL10) and CC (CCL2) chemokines in untreated essential hypertension," International Journal of Immunopathology and Pharmacology, vol. 25, no. 2, pp. 387-395, 2012.
[36] J. Vilček and M. Feldmann, "Historical review: cytokines as therapeutics and targets of therapeutics," Trends in Pharmacological Sciences, vol. 25, no. 4, pp. 201-209, 2004.

[37] C. M. Nishijima, Caracterização do efeito anti-inflamatório e anti-hemorrágico dos extratos e frações enriquecidas de espécies vegetais do projeto temático BIOTA/FAPESP [Dissertação], Universidade Estadual Paulista Júlio de Mesquita Filho, Botucatu, Brazil, 2010.

[38] B. Saad, B. S. Abouatta, W. Basha et al., "Hypericum triquetrifolium-derived factors downregulate the production levels of LPS-induced nitric oxide and tumor necrosis factor- $\alpha$ in THP-1 cells," Evidence-Based Complementary and Alternative Medicine, vol. 2011, Article ID 586470, 7 pages, 2011.

[39] G.-H. Baek, Y.-S. Jang, S.-I. Jeong et al., "Rehmannia glutinosa suppresses inflammatory responses elicited by advanced glycation end products," Inflammation, vol. 35, no. 4, pp. 1232-1241, 2012.

[40] H.-J. Choi, H.-J. Jang, T.-W. Chung et al., "Catalpol suppresses advanced glycation end-products-induced inflammatory responses through inhibition of reactive oxygen species in human monocytic THP-1 cells," Fitoterapia, vol. 86, no. 1, pp. 19-28, 2013.

[41] M. M. Yamamoto, "Casearia silvestris Sw.: Aspectos botânicos, fitoquímicos e farmacológicos," in Monografia-Curso de Especialização em Ciências Farmacêuticas -Produtos Naturais, Universidade Federal do Paraná, Curitiba, Brazil, 1995.

[42] F. E. Kandil, A. M. Soliman, S. R. Skodack, and T. J. Mabry, "A new anticancer tannin and known tannins from Terminalia catapa," Asian Journal of Chemistry, vol. 11, no. 3, pp. 1001-1004, 1999.

[43] M. C. S. Marques, M. G. Cardoso, and M. L. Gavilantes, "Análise fitoquímica das folhas e botões florais do Caryocar brasiliense Camb," in Anais do Seminário Centrooeste de Plantas Medicinais, FESURU, Rio Verde, Brazil, 2000.

[44] S. Cao, P. J. Brodie, M. Callmander et al., "Saponins and a lignan derivative of Terminalia tropophylla from the Madagascar Dry Forest," Phytochemistry, vol. 71, no. 1, pp. 95-99, 2010.

[45] X.-C. Li, H. N. ElSohly, A. C. Nimrod, and A. M. Clark, "Antifungal activity of (-)-epigallocatechin gallate from Coccoloba dugandiana," Planta Medica, vol. 65, no. 8, article 780, 1999.

[46] M. E. Pascual, K. Slowing, E. Carretero, D. Sánchez Mata, and A. Villar, "Lippia: traditional uses, chemistry and pharmacology: a review," Journal of Ethnopharmacology, vol. 76, no. 3, pp. 201214, 2001.

[47] M. V. B. Monteiro, A. K. R. de Melo Leite, L. M. Bertini, S. M. de Morais, and D. C. S. Nunes-Pinheiro, "Topical anti-inflammatory, gastroprotective and antioxidant effects of the essential oil of Lippia sidoides Cham. leaves," Journal of Ethnopharmacology, vol. 111, no. 2, pp. 378-382, 2007.

[48] T. J. Karpanen, T. Worthington, E. R. Hendry, B. R. Conway, and P. A. Lambert, "Antimicrobial efficacy of chlorhexidine digluconate alone and in combination with eucalyptus oil, tea tree oil and thymol against planktonic and biofilm cultures of Staphylococcus epidermidis," Journal of Antimicrobial Chemotherapy, vol. 62, no. 5, pp. 1031-1036, 2008.

[49] R. A. Saraiva, M. K. A. Araruna, R. C. Oliveira et al., "Topical anti-inflammatory effect of Caryocar coriaceum Wittm. (Caryocaraceae) fruit pulp fixed oil on mice ear edema induced by different irritant agents," Journal of Ethnopharmacology, vol. 136, no. 3, pp. 504-510, 2011.

[50] I. Esteves, I. R. Souza, M. Rodrigues et al., "Gastric antiulcer and anti-inflammatory activities of the essential oil from Casearia sylvestris Sw," Journal of Ethnopharmacology, vol. 101, no. 1-3, pp. 191-196, 2005. 
[51] S. Zeghichi, S. Kallithraka, and A. P. Simopoulos, "Nutritional composition of molokhia (Corchorus olitorius) and stamnagathi (Cichorium spinosum)," World review of nutrition and dietetics, vol. 91, pp. 1-21, 2003.

[52] Y.-Y. Yan, Y.-W. Wang, S.-L. Chen, S.-R. Zhuang, and C.-K. Wang, "Anti-inflammatory effects of phenolic crude extracts from five fractions of Corchorus Olitorius L.," Food Chemistry, vol. 138, no. 2-3, pp. 1008-1014, 2013.

[53] J. J. Haringman, D. M. Gerlag, T. J. M. Smeets et al., "A randomized controlled trial with an anti-CCL2 (anti-monocyte chemotactic protein 1) monoclonal antibody in patients with rheumatoid arthritis," Arthritis \& Rheumatism, vol. 54, no. 8, pp. 2387-2392, 2006.

[54] S. Wrigley, Biodiveristy: New Leads for the Pharmaceutical and Agrochemical Industries, Royal Society of Chemistry, Cambridge, UK, 2000.

[55] R. Reyes-Chilpa, C. H. Baggio, D. Alavez-Solano et al., "Inhibition of gastric $\mathrm{H}^{+}, \mathrm{K}^{+}$-ATPase activity by flavonoids, coumarins and xanthones isolated from Mexican medicinal plants," Journal of Ethnopharmacology, vol. 105, no. 1-2, pp. 167-172, 2006.

[56] S. P. Almeida, C. E. B. Proença, S. M. Sano et al., Cerrado: Espécies vegetais úteis, Empresa Brasileira de Pesquisa Agropecuária do Brasil (EMBRAPA), Brasília, Brazil, 1994.

[57] M. C. Souza, Triagem da atividade anti-Helicobacter pylori in vitro de plantas medicinais do cerrado mato-grossense e atividade anti-Helicobacter pylori in vivo do extrato hidroetanólico e fração diclorometânica $\left(\mathrm{DCM}_{2}\right)$ de Calophyllum brasiliense Camb. (Clusiaceae) [Dissertação], Universidade Federal do Mato Grosso, Mato Grosso, Brazil, 2008.

[58] R. F. Vieira and M. V. M. Martins, "Recursos genéticos de plantas medicinais de cerrado: uma compilação de dados," Brazilian Journal of Medicinal Plants, vol. 3, pp. 13-36, 2000.

[59] M. Brandão, J. P. Laca-Buendía, and J. F. Macedo, Árvores nativas e exóticas do Estado de Minas Gerais, EPAMIG, Belo Horizonte, Brazil, 2002.

[60] D. S. Raslan, C. M. Jamal, D. S. Duarte, M. H. Borges, and M. E. De Lima, "Anti-PLA2 action test of Casearia sylvestris Sw," Bollettino Chimico Farmaceutico, vol. 141, no. 6, pp. 457-460, 2002.

[61] H. Morita, M. Nakayama, H. Kojima et al., "Structures and cytotoxic activity relationship of casearins, new clerodane diterpenes from Casearia sylvestris Sw," Chemical \& Pharmaceutical Bulletin, vol. 39, no. 3, pp. 693-697, 1991.

[62] D. R. A. Mans, A. B. da Rocha, and G. Schwartsmann, "Anticancer drug discovery and development in Brazil: targeted plant collection as a rational strategy to acquire candidate anti-cancer compounds," Oncologist, vol. 5, no. 3, pp. 185-198, 2000.

[63] S. L. da Silva, P. M. S. Figueredo, and T. Yano, "Antibacterial and antifungal activities of volatile oils from Zanthoxylum rhoifolium leaves," Pharmaceutical Biology, vol. 44, no. 9, pp. 657-659, 2006.

[64] M. H. Gordon, "Dietary antioxidants in disease prevention," Natural Product Reports, vol. 13, no. 4, pp. 265-273, 1996.

[65] H. Wang, M. G. Nair, G. M. Strasburg et al., "Antioxidant and antiinflammatory activities of anthocyanins and their aglycon, cyanidin, from tart cherries," Journal of Natural Products, vol. 62, no. 2, pp. 294-296, 1999.

[66] F. G. Coe and G. J. Anderson, "Screening of medicinal plants used by the Garifuna of eastern Nicaragua for bioactive compounds," Journal of Ethnopharmacology, vol. 53, no. 1, pp. 29-50, 1996.

[67] M. C. Zamora-Martinez and C. N. P. Pola, "Medicinal plants used in some rural populations of Oaxaca, Puebla and Veracruz,
Mexico," Journal of Ethnopharmacology, vol. 35, no. 3, pp. 229257, 1992.

[68] G. S. Vendruscolo, Estudo etnobotânico das plantas utilizadas como medicinais por moradores do bairro Ponta Grossa, Porto Alegre, Rio Grande do Sul [Dissertação], Universidade Federal do Rio Grande do Sul, Porto Alegre, Brazil, 2004.

[69] A. de Lima, A. M. O. e Silva, R. A. Trindade, R. P. Torres, and J. Mancini-Filho, "Composição química e compostos bioativos presentes na polpa e na amêndoa do pequi (Caryocar brasiliense, camb.)," Revista Brasileira de Fruticultura, vol. 29, no. 3, pp. 695698, 2007.

[70] J. H. Cano and G. Volpato, "Herbal mixtures in the traditional medicine of Eastern Cuba," Journal of Ethnopharmacology, vol. 90, no. 2-3, pp. 293-316, 2004.

[71] J. L. González-Guevara, H. Vélez-Castro, K. L. González-García et al., "Flavonoid glycosides from Cuban Erythroxylum species," Biochemical Systematics and Ecology, vol. 34, no. 6, pp. 539-542, 2006.

[72] F. J. A. Matos, Plantas Medicinais, Imprensa Universitária, Fortaleza, Brazil, 2000.

[73] R. G. Coelho, W. Vilegas, K. F. Devienne, and M. S. G. Raddi, "A new cytotoxic naphthopyrone dimer from Paepalanthus bromelioides," Fitoterapia, vol. 71, no. 5, pp. 497-500, 2000.

[74] R. R. D. Moreira, I. Z. Carlos, and W. Vilegas, "Macrophage activation by Paepalanthus spp. extracts," Revista Brasileira de Farmacognosia, vol. 9-10, no. 1, pp. 37-42, 2000.

[75] U. Nyman, P. Joshi, L. B. Madsen et al., "Ethnomedical information and in vitro screening for angiotensin-converting enzyme inhibition of plants utilized as traditional medicines in Gujarat, Rajasthan and Kerala (India)," Journal of Ethnopharmacology, vol. 60, no. 3, pp. 247-263, 1998.

[76] M. Báthori and Z. Pongrácz, "Phytoecdysteroids—from isolation to their effects on humans," Current Medicinal Chemistry, vol. 12, no. 2, pp. 153-172, 2005.

[77] S. R. Gupta, S. A. Nirmal, R. Y. Patil, and G. S. Asane, "Antiarthritic activity of various extracts of Sida rhombifolia aerial parts," Natural Product Research, vol. 23, no. 8, pp. 689-695, 2009.

[78] B. Somanadhan, G. Varughese, P. Palpu et al., "An ethnopharmacological survey for potential angiotensin converting enzyme inhibitors from Indian medicinal plants," Journal of Ethnopharmacology, vol. 65, no. 2, pp. 103-112, 1999.

[79] S. Nammi, R. Gudavalli, B. S. Ravindra Babu, D. S. Lodagala, and K. M. Boini, "Possible mechanisms of hypotension produced $70 \%$ alcoholic extract of Terminalia arjuna (L.) in anaesthetized dogs," BMC Complementary and Alternative Medicine, vol. 3, article 5, 2003.

[80] Y. Sato, H. Oketani, K. Singyouchi et al., "Extraction and purification of effective antimicrobial constituents of Terminalia chebula Retz. against methicillin-resistant Staphylococcus aureus," Biological \& Pharmaceutical Bulletin, vol. 20, no. 4, pp. 401-404, 1997.

[81] F. E. Kandil, A. M. Soliman, S. R. Skodack, and T. J. Mabry, "A new anticancer tannin and known tannins from Terminalia cattapa," Asian Journal of Chemistry, vol. 11, no. 3, pp. 1001-1004, 1999.

[82] C. D. de Souza and J. M. Felfili, "The utilization of medicinal plants in the region of Alto Paraíso of Goiás, GO, Brazil," Acta Botânica Brasílica, vol. 20, pp. 133-142, 2006. 


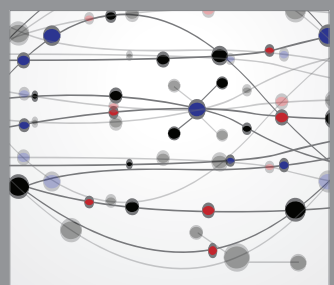

The Scientific World Journal
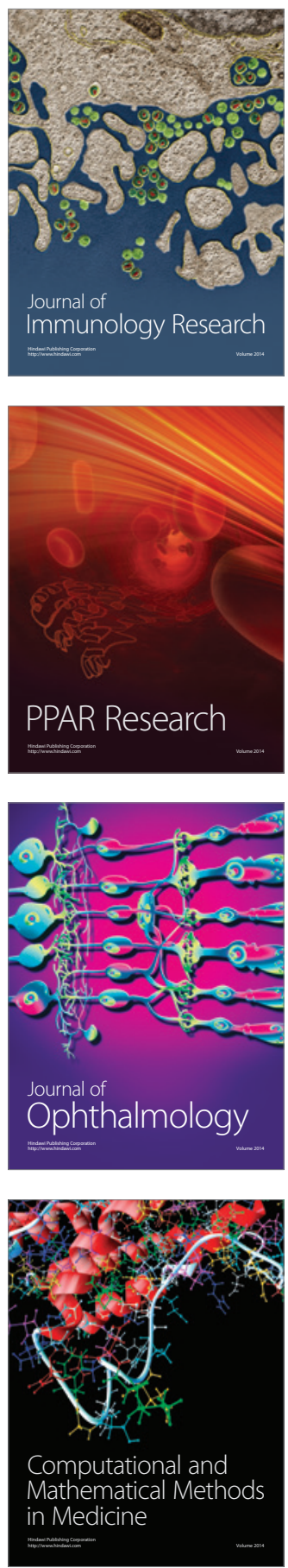

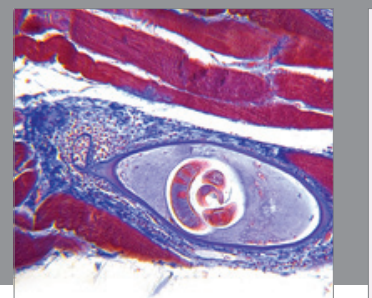

Gastroenterology

Research and Practice
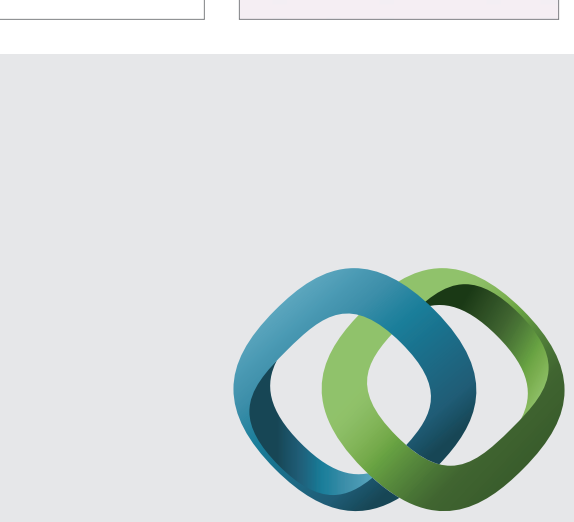

\section{Hindawi}

Submit your manuscripts at

http://www.hindawi.com
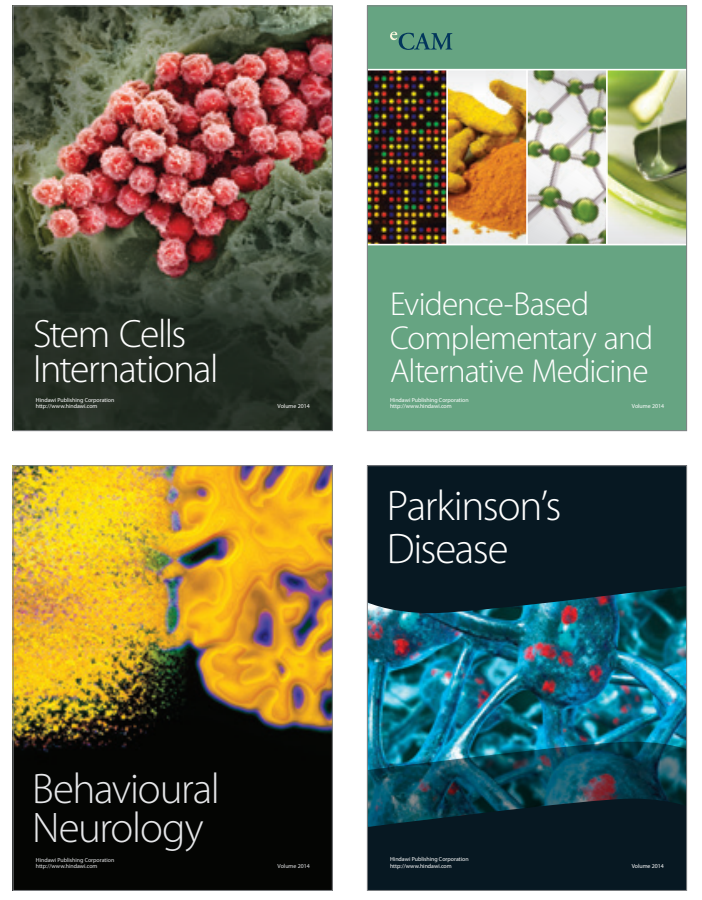
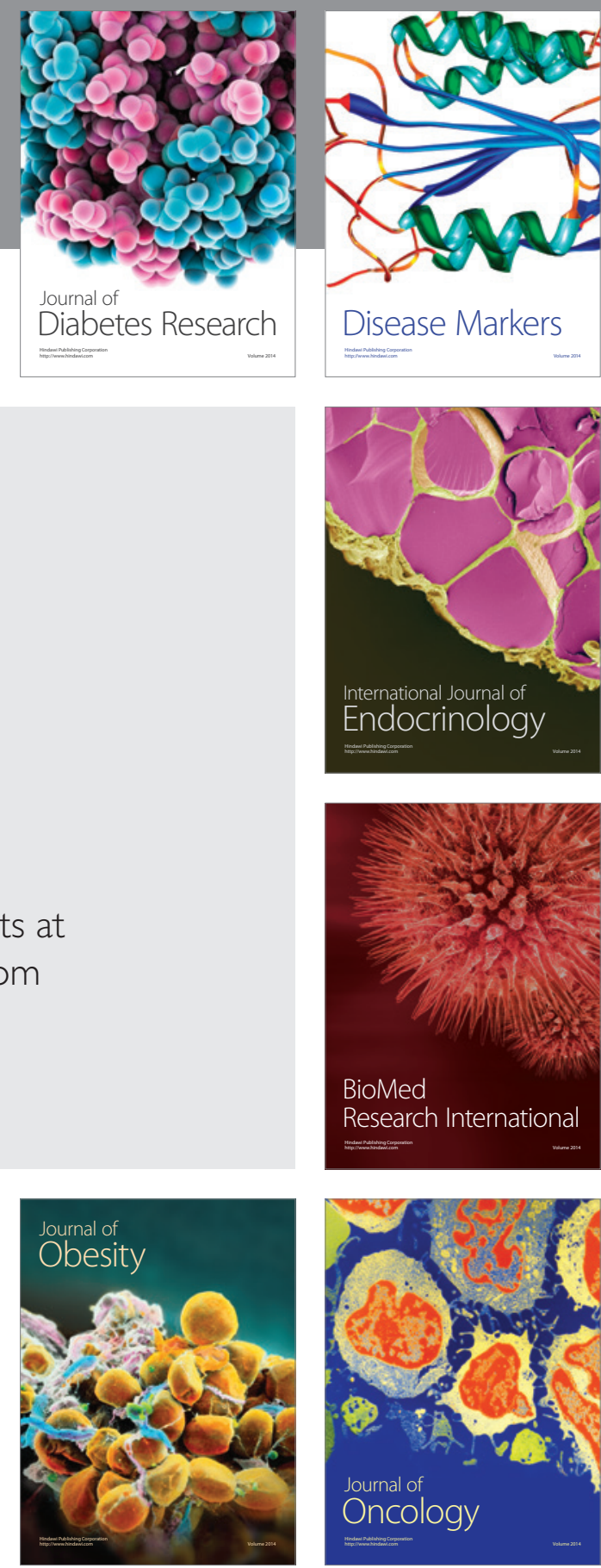

Disease Markers
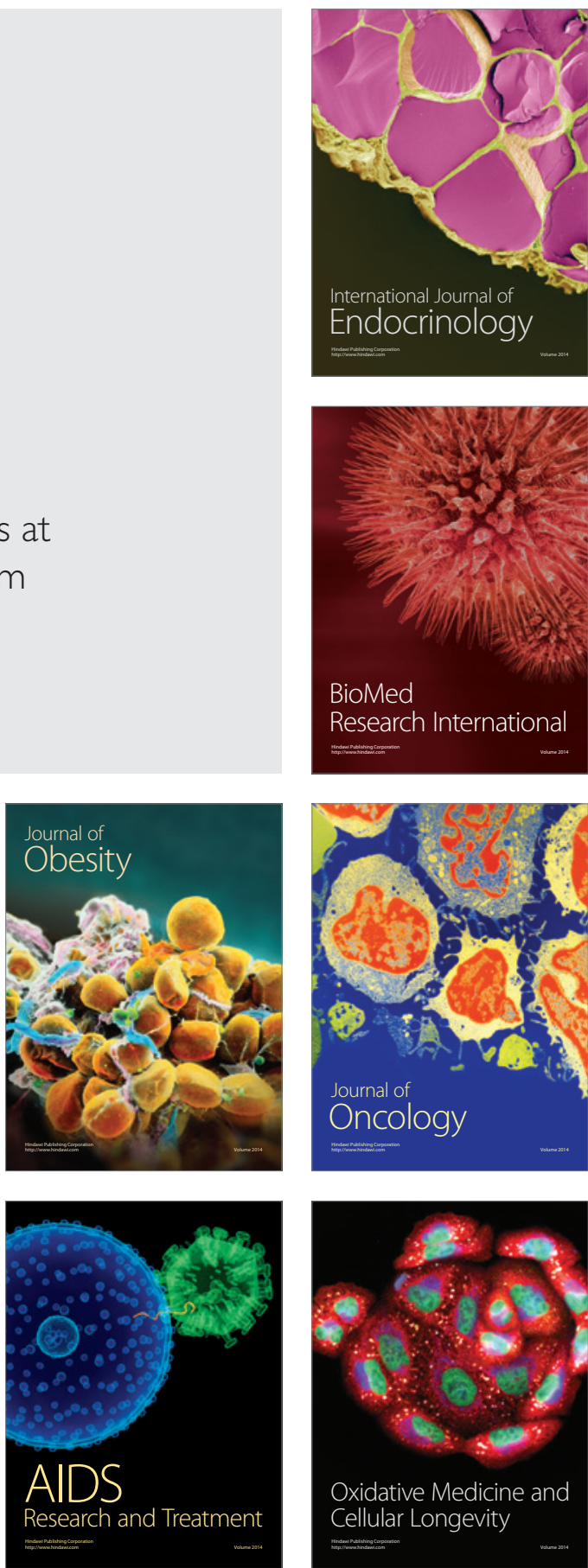